\title{
Effect of mode of operation, substrate and final electron acceptor on single-chamber membraneless microbial fuel cell operating with a mixed community
}

\author{
Fabrizio Vicari, Michele Albamonte, Alessandro Galia, Onofrio Scialdone* \\ Dipartimento dell'Innovazione Industriale e Digitale (Ingegneria Chimica Gestionale Informatica Meccanica), University of Palermo Viale delle Scienze, Ed. 6, 90128 \\ Palermo, PA, Italy
}

\section{A R T I C L E I N F O}

\section{Keywords:}

Microbial fuel cell

Bio-electrochemical system

Membraneless

Fermentable

Non-fermentable substrate

Glycerol

\begin{abstract}
A B S T R A C T
Waste minimization and circular thinking are to be achieved in order to cope with the limited amount of resources of our planet. In this perspective, bio-electrochemical systems (BESs) can contribute to the global balance with their ability to extract chemical residual energy from wastewater and transform it directly into electrical current. BESs development has been limited by the cost connected to reactor design, in which membranes and cathode catalyst constituted a major drawback. In this paper we report the optimization process of a simple reactor without membranes or precious catalyst that produced $47.1 \mathrm{~mW} \mathrm{~m}{ }^{-2}$, which is more than what achieved with configurations including membranes, operating in similar conditions (glycerol as substrate and hydraulic retention times of 3 days). In opposition to what is usually reported for conventional divided microbial fuel cells (MFCs), we have found that in this kind of reactor fermenting substrates (mainly glycerol) can give higher current density than non-fermentable ones (acetate). Feeding modality and proper electrode orientation were confirmed to have a dramatic impact on power output. Finally, a possible niche for the exploitation of our single chamber membraneless MFC was pointed out to exist in bio-refinery industry.
\end{abstract}

\section{Introduction}

\subsection{Bio-electrochemical systems for waste valorization}

Global energy consumption was $1.5 \times 10^{9} \mathrm{MWh}$ in 1850 ([1]) and global population was of about 1.26 billion people (United Nations Population Division) for a specific energy consumption of about 1.16 MWh year $^{-1}$ person $^{-1}$. The same calculation for the 7 billion people population of 2017 is of about 4.19 MWh year $^{-1}$ person $^{-1}$ (our estimate). This means that energy demand is not linearly related to the growth of population. The reason for this un-linearity has to be searched in our development model, based on the assumption that the procapita production has always to rise, against the natural concept of stationarity, which belongs to every eco-system [2]. In order to get closer to stationarity, wastes have to be avoided. It is calculated that annually $1.5 \times 10^{8}$ MWh are wasted as municipal, industrial, and animal wastewater [3]. Bio-Electrochemical Systems (BESs) are electrochemical devices developed for the direct conversion of the residual chemical energy of wastewater into electric current [3]. Exoelectrogens bacteria are employed, capable to close their respiratory electron chain on the surface of an electrode [4]. Up to know, BESs were used to extract energy from a multitude of wastes, such as distillery, food, animal carcass, brewery, biodiesel, manure, cheese, urine, feces, bad wine, old juices and composite vegetable [5]. In various cases, BES obtained relatively high energy conversion, but still their use is limited to the laboratory scale, since scale up seems to embed some major limitations. First of all, the ion-exchange membranes used for the separation of the two electrodic compartments are very expensive and brittle [6], making their use economically unsustainable. Sustainability can be improved by the integration of energy production with wastewater abatement in both compartments [7-9]. As an example, a water contaminated by acid orange 7 , was first abiotically decolored in the cathodic compartment and, then, residual carboxylic acids were fed to the anodic bio-community [10]. Economics figures show that another constrain to BESs scale-up is represented by the cost of the catalyst that are used to improve the Oxygen Reduction Reaction (ORR) on cathode surface [11].

Many attempts to overcome these limitations were done; notable is the single chamber MFC implemented by Prof. Carlo Santoro and coworkers that showed how a membrane-free MFC without cathode catalyst can obtain the same results of an identical MFC operating with a Pt catalyst thanks to an efficient cathodic biofilm [27]. In authors opinion,

\footnotetext{
* Corresponding author.

E-mail address: onofrio.scialdone@unipa.it (O. Scialdone).
} 
Table 1

Comparison of single chamber membraneless (SCML) MFC without air cathode.

\begin{tabular}{|c|c|c|c|c|c|c|}
\hline Cell-type & Inoculum & Peak power $\left[\mathrm{mW} \mathrm{m}^{-2}\right]$ & Substrate & Size $[L]$ & $\mathrm{CE}^{\mathrm{b}}[\%]$ & Ref. \\
\hline Sediment & Marine sediment & 1.4 & Sediment organic matter & - & - & [12] \\
\hline Sediment & Polluted riverbank & 7.5 & Sediment organic matter & 0.5441 & - & [13] \\
\hline Sediment & Farm manure & 5 & Manure & 7 & - & [14] \\
\hline Sediment & Dairy wastewater & $0.51^{\mathrm{a}}$ & Dairy wastewater & - & - & [15] \\
\hline Solid phase & Composite food & 4 & Waste food & 0.55 & - & [16] \\
\hline SCML & WWTP & 220 & Carbohydrates & 0.2 & - & [17] \\
\hline SCML & Shewanella putrefaciens & 37.5 & Lysogeny broth & 0.06 & 1.3 & {$[18]$} \\
\hline Baffled & Anaerobic paper sludge & 74 & Glucose & 63 & - & [19] \\
\hline GAC-SCML $^{\mathrm{C}}$ & WWTP & $0.25^{\mathrm{a}}$ & Acetate & 0.15 & $80-15$ & {$[20]$} \\
\hline DF-SCML $^{\mathrm{d}}$ & Anaerobic activated sludge & 37.4 & Glucose & 0.85 & - & {$[21]$} \\
\hline SCML & WWTP & 100 & Municipal wastewater & 45 & $10-24$ & {$[22]$} \\
\hline SCML & Bacillus subtilis & 19 & Glucose & 0.028 & 11 & {$[23]$} \\
\hline SCML & Previous MFC & $58^{\mathrm{a}}$ & Urine & 5 & - & {$[24]$} \\
\hline SCML & Previous MFC & $64^{\mathrm{a}}$ & Urine & 30 & - & {$[25]$} \\
\hline SCML & WWTP & $22.7^{\mathrm{a}}$ & Acetate & 1.1 & 4.4 & {$[26]$} \\
\hline SCML & WWTP & 47.1 & Glycerol & 0.6 & 1.48 & This study \\
\hline
\end{tabular}

a Recalculated and normalized on cathode surface.

${ }^{\mathrm{b}}$ Coulombic efficiency (CE).

c Granular activated carbon (GAC).

${ }^{\mathrm{d}}$ Down flow (DF).

a third constrain to BESs scale-up can be given by the utilization of aircathodes which are gas-diffusion electrodes (GDEs) capable to enhance oxygen reduction [28-30], but increasing the complexity and the cost of the system. In order to limit these disadvantages, various researchers have investigated the utilization of single chamber membraneless (SCML) not equipped with air-cathodes (Table 1). In configurations derived from early sediment MFCs, anode is submerged into a detritic layer were oxygen is scavenged by microbes while cathode is in the overlying oxygenated water [12-16]. From an energetic point of view, these sediment-derived MFCs are currently regarded as the most realistic way for BES technology development [31]. SCML-MFC without an air cathode were developed also without any physical delimitation between the two environments [17-21]. Even if best results, in terms of power production, were achieved by Liu and co-workers [17] (see Table 1), the most promising approach to MFC scale-up seems to be the one adopted by the group of Ieropoulos that has conducted a successful systematic attempt to develop a system independent from any external peripherals and capable to power small electronic devices using the urine of a single individual [24,25]. The analysis of the performances of divided MFCs underlines that, as in any other biological reactor, substrate plays a fundamental role [32]. Pant research team has extensively reviewed the most of the substrate used in MFCs up to now in two different papers that can give to the reader a comprehensive understanding of the subject $[5,33]$. However, in the case of SCML-MFCs without an air cathode, scarce information on the effect of the substrate are present in literature. In particular, it would be very important to understand if the nature of the substrate has the same effects on both divided (i.e. with a membrane) and undivided MFCs (without any separator) exposed to air. Hence, in this paper, we have performed a detailed investigation on the effect of the substrate in both divided and undivided cells. The possibility of exploit the nitrogen cycle for biocathode functioning was taken into account. The effect of reactor feeding modality and electrode orientation on power production was also evaluated. It is worth to mention that we have found that the effect of the substrate in the case of undivided MFCs is different with respect to that achieved in divided cells.

\section{Materials and methods}

\subsection{Reactor setup and operation}

Single chamber membraneless microbial fuel cells (SCML-MFCs) with a total working volume of $60 \mathrm{~mL}$ were implemented into simple undivided electrochemical cell as described earlier [18]. Briefly, anode was a $10.5 \mathrm{~cm}^{2}$ piece of carbon felt while cathode was a piece of compact graphite of the same surface. This last was rotated to get horizontality at the interphase between liquid and headspace in a specific set of experiments. Reactor were inoculated with $20 \mathrm{~mL}$ of aerobic sludge obtained from the aeration thank of a University of Cape Town Modified (UCTM) pilot plant available in our institution [34]. Three different way of feeding were compared:

- Batch. During batch tests $50 \mathrm{~mL}$ of solution were exchanged once total organic carbon (TOC) concentration was not changed appreciably. Batch averaged duration was of 2 weeks.

- Semi-continuous. Semi-continuous modality was implemented replacing every day $20 \mathrm{~mL}$ i.e. imposing a hydraulic retention time (HRT) of 3 days.

- Continuous. Continuous mode was implemented thanks to the use of two syringe pumps (NE-300, New Era Pumps Systems, Inc.) push/ pulling two $60 \mathrm{~mL}$ syringe at a flow rate of $0.84 \mathrm{~mL} \mathrm{~h}^{-1}$ to obtain the same HRT of 3 days.

To test nitrate effect on bio-cathodic metabolism, $1 \mathrm{~mL}$ of $2 \mathrm{M}$ $\mathrm{NH}_{4} \mathrm{NO}_{3}$ (Sigma-Aldrich) was poured every $60 \mathrm{~mL}$ of medium for selected experiments (final concentration $33 \mathrm{mM}$ ). Every cell was continuously stirred at $300 \mathrm{rpm}$ with a magnetic stirrer (AREX, VELP Scientifica Srl). During normal operations, a $1 \mathrm{k} \Omega$ external resistor was used as cell load. Results obtained with SCML cells were also compared with $\mathrm{H}$-type reactor assembled with two $100 \mathrm{~mL}$ glass bottles jointed by a horizontal glass tube housing a Nafion ${ }^{\mathrm{TM}} 117$ (DuPont) membrane. Electrodes and load were exactly the same of the undivided reactor; compartments were opened to the atmosphere and stirred at $300 \mathrm{rpm}$. Catholyte consisted of pH 3 DM without carbon (sulfuric acid acidification). Experiments were performed at room temperature $\left(25 \pm 3^{\circ} \mathrm{C}\right)$.

\subsection{Media and analytics}

Two defined media (DM) were prepared with a different $\mathrm{Na}_{2} \mathrm{HPO}_{4}$ and $\mathrm{KH}_{2} \mathrm{PO}_{4}$ ratio. When glucose or glycerol were used (fermenting substrates) $1.51 \mathrm{~g} \mathrm{~L}^{-1}$ of $\mathrm{Na}_{2} \mathrm{HPO}_{4}$ and $0.182 \mathrm{~g} \mathrm{~L}^{-1}$ of $\mathrm{KH}_{2} \mathrm{PO}_{4}$ were dosed, while $0.731 \mathrm{~g} \mathrm{~L}^{-1}$ of $\mathrm{Na}_{2} \mathrm{HPO}_{4}$ and $0.685 \mathrm{~g} \mathrm{~L}^{-1}$ of $\mathrm{KH}_{2} \mathrm{PO}_{4}$ were added in the case of lactate and acetate (non-fermenting substrates). The other components for liter of both solutions were: $8 \mathrm{~g}$ of NaCl, $0.5 \mathrm{~g}$ of $\mathrm{NH}_{4} \mathrm{Cl}, 0.2 \mathrm{~g}$ of $\mathrm{KCl}, 0.1 \mathrm{~g}$ of $\mathrm{MgSO}_{4}, 0.133 \mathrm{~g}$ of $\mathrm{CaCl}_{2}, 10 \mathrm{~mL}$ of 
Vitamin Mix and $10 \mathrm{~mL}$ of Trace Mineral Mix. Glycerol, glucose, lactate and acetate were poured in different concentrations in order to assess their effect on cell performance. All reagents were provided by Sigma Aldrich. Media were heat-sterilized at $121^{\circ} \mathrm{C}$ for $20 \mathrm{~min}$. A saturated calomel electrode (SCE) ( $\mathrm{E}=0.241 \mathrm{vs} \mathrm{SHE}$ ) was used as reference to measure electrodes open circuit potentials (OCP). Total organic carbon (TOC) concentration of $0.45 \mu \mathrm{m}$ filtered samples was measured every 2 days as Non-Purgeable Organic Carbon (NPOC) by a TOC analyzer (TOC-L, Shimadzu). Also $\mathrm{pH}$ was monitored with the same frequency with a specific probe (HI8314, Hanna Instruments). A multimeter datalogger (2700, Keithley) connected to a PC was used to register cell voltage during normal operation with a frequency of 1 data $\mathrm{h}^{-1}$, while a potentiostat/galvanostat (Autolab PGSTAT30, EcoChemie) was used to perform polarizations implemented with a linear sweep voltammetry (LSV) from OCP to $0.001 \mathrm{~V}$ at a scan rate of $1 \mathrm{mV} \mathrm{s}^{-1}$. Before polarization, stationary phase was always reached and a minimum of two weeks was waited; then cells were left to develop the OCP for at least $5 \mathrm{~h}$. In the last set of experiments, when continuous mode was used, a minimum of one week separated one polarization and the other, in order to adapt the biotic component to the new conditions.

\subsection{Calculations}

From voltage $V$ and external resistance $R_{\text {ext }}$, current $I$ and power $P$ were derived from $\mathrm{Ohm}$ and Joule laws; then current $i$ and power $p$ densities were calculated using electrode projected surface of $10.5 \mathrm{~cm}^{2}$. The slope of the straight line interpolating the central portion of the polarization curve (I/V plane) was used to compute the internal resistance of the cells $R_{\text {int }}$. Coulombic efficiency $C E$ was calculated as described in details in [18]. Briefly, $C E$ is the ratio of the total energy produced by the system and the theoretical amount of energy corresponding to the depleted fuel.

\section{Results and discussions}

\subsection{Comparison between fermentable and non-fermentable substrates}

Four identical SCML-MFCs were simultaneously started in batch conditions with vertical electrodes. Every SCML-MFC was inoculated as described in "Materials and methods" section, with the same DM but different electron sources. Glycerol and glucose as fermentable substrates and acetate and lactate as non-fermentable ones were selected as carbon sources and assigned to specific reactors. In these initial tests, the amount of these compounds was tuned to give the same carbon concentration: $7500 \mathrm{mg}_{\mathrm{c}} \mathrm{L}^{-1}$. A cycle was considered to be finished when the carbon content of the media did not change appreciably in time, reflecting a reduced biological activity. This was found to be a period of about two weeks. For the first week, both current produced and carbon consumption were very low for every SCML-MFC, but starting from the second week, an appreciable amount of energy was converted into electricity (see Fig. 1). Power production was growing up to the beginning of the 3rd month.

The experiments were prolonged for 4 months. Current density of the cells for the final two weeks is reported in Fig. 2A as a temporal average. Feeding a cell with glycerol resulted in best performances $\left(11.4 \mathrm{~mA} \mathrm{~m}^{-2}\right)$. Just slightly lower currents were obtained with the other fermentable substrate (glucose) while significantly lower values were achieved with the non-fermentable substrates. In particular, the worse performance was obtained with acetate $\left(4.4 \mathrm{~mA} \mathrm{~m}^{-2}\right)$. These results are very different from that achieved in conventional divided MFCs [35-40], where non-fermentable substrates (mainly acetate) gave usually more power and current than fermentable ones [37]. An example of conventional divided reactor in a very similar scenario (HRT of 3 days) is given by the work of Rodrigo group [40], where acetate feeding increased reactor performances with respect to glycerol, ethanol and fructose.

These outcomes are usually attributed to the reduced bio-diversity induced by the use of non-fermentable substrates that leads to a forced selection of electrogens. Indeed, when defined media (DM) is used, bacteria adapt to it opening specific metabolic pathways for substrate utilization [41]. Strain whose metabolism does not allow the usage of that substrate die or form spore to protect themselves [42]. Acetate is a very simple compound that derives from higher order metabolism, as for the fermentation of glycerol [43], limiting the possibility of diversification. On the other hand, in our reactor, biodiversity is essential in order to sustain both anodic and cathodic processes simultaneously, since it was shown that the bio-cathodic process may take advantage of taxonomy richness and evenness [44]. In this context, fermentable substrates are likely to increase bio-diversity resulting in better performance.

\subsection{Effect of ammonia nitrate addition}

When Zhu and co-workers developed a liter scale membraneless MFC, they have inoculated the anodic chamber with an anaerobic, methanogenic culture and the cathodic one with a denitrifying consortium in order to use the proper catalytic activity for each electrode [45]. Also Ieropoulos reactor was hypothesized to take advantage of the use of biological nitrogen redox cycle on cathode surface [25]. The UCTM plant where sludge was collected for MFCs inoculation contains denitrifying bacteria capable to accomplish nitrate reduction [34], so the bacterial communities into our MFCs had the potentiality to accomplish substrate oxidation at the anode and nitrate reduction at the cathode simultaneously. It is worth to mention that, when denitrifying bacteria are present in bio-cathodes communities [46], the simple addition of $\mathrm{NO}_{3}{ }^{-}$can enhance their performance [47]. To evaluate this possibility, after a first period of about 60 days, $1 \mathrm{~mL}$ of $2 \mathrm{M} \mathrm{NH}_{4} \mathrm{NO}_{3}$ was added to all the cells at the beginning of every batch test (final concentration $33 \mathrm{mM}$, see Fig. 2B). Under this condition, current density increased in all cells. As an example, the cell fed with lactate gave more than twice his previous current reaching $22 \mathrm{mAm}^{-2}$. Current density was constantly higher until nitrates were provided to the SCML-

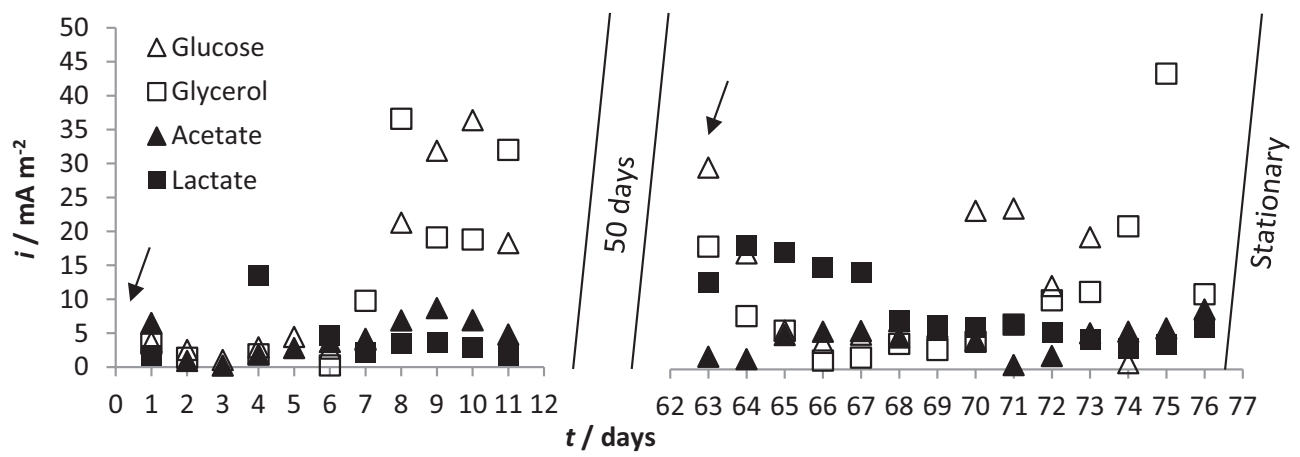

Fig. 1. Daily averaged current density of 4 identical single chamber membraneless MFCs operated in batch-mode for 4 months. Two different batch cycles are here reported for start-up and later on operations. Anode: carbon felt. Cathode: vertical compact graphite. Glucose $\Delta$, Glycerol $\square$, acetate $\mathbf{\Delta}$ and lactate $\boldsymbol{\square}$ based defined media were compared at the same total organic carbon of $7500 \mathrm{mg} \mathrm{L}^{-1}$. Arrows: medium exchange. 
A)

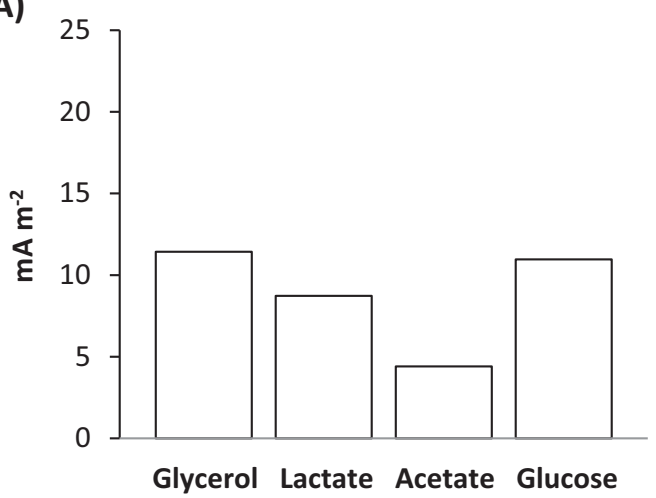

B)

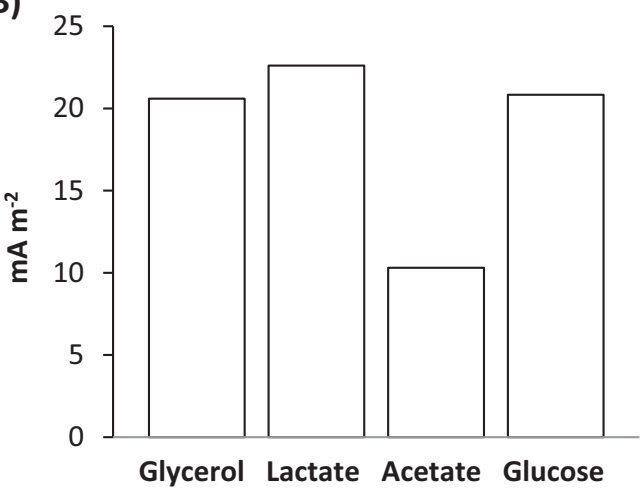

Fig. 2. Averaged current density for the stationary phase of 4 identical single chamber membraneless MFCs operated in batch for 4 months. Anode: carbon felt. Cathode: compact graphite. Glycerol, lactate, acetate and glucose based defined media were compared at the same total organic carbon of $7500 \mathrm{mg} \mathrm{L}^{-1}$, in the absence A) and in the presence B) of ammonia nitrate $(33 \mathrm{mM})$ as cathodic final electron acceptor.
MFC and rapidly reduced in the absence of such a supplement, meaning that the increment was stationary and reversible. Hence, it was confirmed that it is possible to increase the power output of SCML-MFC operating with a mixed community that takes advantage of the nitrogen cycle.

\subsection{Effect of cell-feeding modality and substrate concentration}

Other three SCML-MFCs were started as described earlier. In this case, after a first batch cycle used by bacteria for acclimation (data not shown), cells mode was switched to semi-continuous, with a hydraulic retention time (HRT) of 3 days. Ammonia nitrate was included in the media (final concentration $33 \mathrm{mM}$ ). The three SCML-MFCs were fed with different amounts of glycerol as electron source in order to evaluate also the effect of the concentration of the substrate. Changing feeding modality had a massive effect on cells behavior: first, a faster acclimation was achieved, recording very stable values yet after 2 weeks against the three months required in batch (compare Figs. 1 and $3 \mathrm{~A}$ ); second, higher current density of $26.0 \mathrm{~mA} \mathrm{~m}^{-2}$ was achieved in semi-continuous mode with respect to the $20.6 \mathrm{~mA} \mathrm{~m}^{-2}$ of the batch one.

TOC measure has revealed that in both cases the availability of carbon was not limiting current generation (final concentration $\approx 3300 \mathrm{mg} \mathrm{L}^{-1}$ in batch and $\approx 4500 \mathrm{mg} \mathrm{L}^{-1}$ for the semi-continuous). Hence the reason for the increased current production can be attributed to the constant availability of easily degradable glycerol and the contextual removal of catabolites such as volatile fatty acids (VFA) that can interfere with bacterial activity [48]. This difference in averaged current production between batch and semi-continuous modalities is also in line to what already shown for air-cathode MFCs [49]. Higher $\left(10 \mathrm{~g}_{\mathrm{c}} \mathrm{L}^{-1}\right)$ and lower $\left(3 \mathrm{~g}_{\mathrm{c}} \mathrm{L}^{-1}\right)$ carbon contents were used to feed other two MFCs. The best result of $58.6 \mathrm{~mA} \mathrm{~m}^{-2}$ was obtained for a carbon content of $3 \mathrm{~g}_{\mathrm{c}} \mathrm{L}^{-1}$ corresponding to a concentration of $\approx 7.6 \mathrm{~g} \mathrm{~L}^{-1}$ of glycerol. The higher the amount of carbon, the lower was the current density observed (Fig. 3B). Similar results were obtained by Asensio et al. when different concentration of sodium acetate were fed to six identical divided reactors operating at the same HRT adopted in this study (3 days) [40]. In that case, a linear increase was recorded for chemical oxygen demand (COD) ranging from 500 to $5000 \mathrm{mg}_{\mathrm{O} 2} \mathrm{~L}^{-1}$, but current production decreased substantially when 10,000 and $20,000 \mathrm{mg}_{\mathrm{O} 2} \mathrm{~L}^{-1}$ were adopted [40].

Present experiment outcome is connected with $\mathrm{pH}$ variation shown in Fig. 4, where to a higher carbon content corresponds a lower pH. A decrease in $\mathrm{pH}$ during glycerol anaerobic digestion can be attributed to the accumulation of VFA that are responsible for bacterial activity inhibition [50]. This could have affected exoelectrogenic population, leading to the lowest coulombic efficiency recorded $(0.01 \%)$ and can also be the reason for a reduced substrate utilization when carbon content exceeded $7.5 \mathrm{~g} \mathrm{~L}^{-1}$ (see Fig. 4).

The best performing concentration of $3 \mathrm{~g}_{\mathrm{c}} \mathrm{L}^{-1}$ of glycerol was then used to test the effect of continuous feeding modality. In this case, a current density of about $59 \mathrm{~mA} \mathrm{~m}^{-2}$ was obtained, similar to that achieved by the semi-continuous cell $\left(58 \mathrm{~mA} \mathrm{~m}^{-2}\right)$, underlining that the HRT of 3 days was properly modulated also with discontinuous feeding, avoiding catabolites accumulation. Nevertheless, two main results were achieved:

i) acclimation stage lasted the minimum ever experienced: in about 1 day cell was already giving significant power, even if power growth lasted about one week;

ii) voltage fluctuation was minimized; while in batch and semi-continuous modes, periodical fluctuations were of the same order of

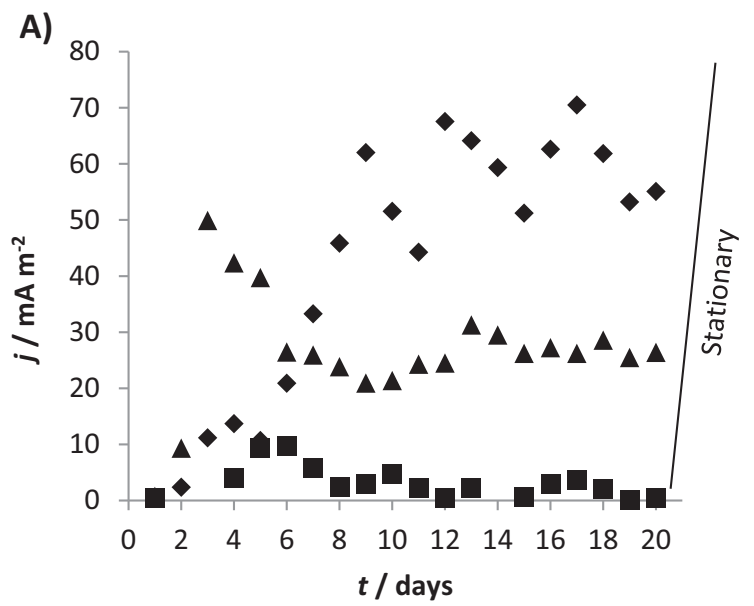

A)

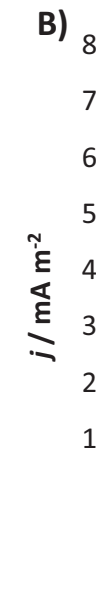

Fig. 3. SCML-MFCs operated in semi-continuous mode with a hydraulic retention time of 3 days. Anode: carbon felt. Cathode: compact graphite. Glycerol based defined media at three different carbon concentrations ( $10,000 \mathrm{mg}_{\mathrm{c}} \mathrm{L}^{-1}, \mathbf{A}$ $7500 \mathrm{mg}_{\mathrm{c}} \mathrm{L}^{-1}$, $3000 \mathrm{mg}_{\mathrm{c}} \mathrm{L}^{-1}$ ). a) Daily averaged current density; b) 21 days averaged current density. 


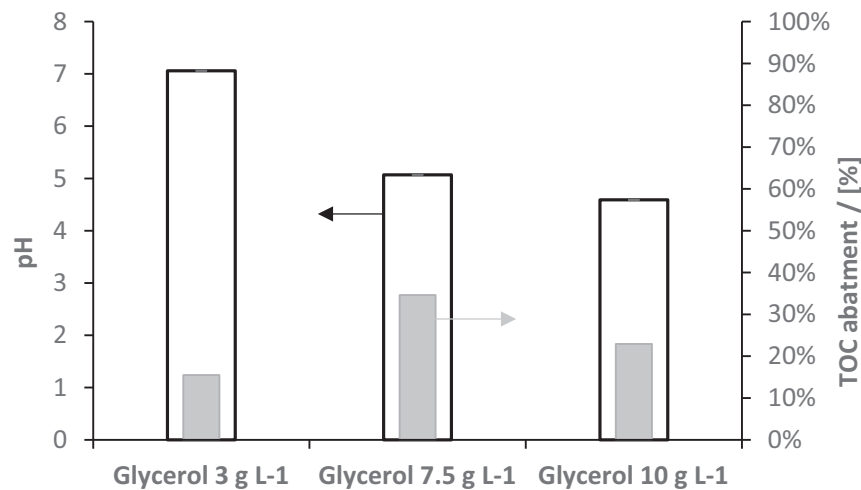

Fig. 4. Total organic carbon (TOC) removal (right) and pH (left) of SCML-MFCs operated in semi-continuous mode with a hydraulic retention time of 3 days. Anode: carbon felt. Cathode: compact graphite. Glycerol based defined media at three different carbon concentrations $\left(10,000 \mathrm{mg}_{\mathrm{c}} \mathrm{L}^{-1}, 7500 \mathrm{mg}_{\mathrm{c}} \mathrm{L}^{-1}, 3000 \mathrm{mg}_{\mathrm{c}} \mathrm{L}^{-1}\right)$ were compared.

magnitude of the energy produced, in this case cell experienced a maximum variation of the $24 \%$ in the daily averaged current production (see Fig. 6 as example of the continuous feeding).

\subsection{Divided reactor comparison}

Along with the SCML-MFCs operated in semi-continuous regimen, two conventional H-type divided MFCs were started using saline solution as catholyte. The anodic compartment of these devices was operated identically to the SCML ones, with an HRT of 3 days and the same DM described above. Since it was chosen to operate these H-type MFCs with an abiotic cathode, nitrate was not added to catholyte. Sodium acetate and glycerol as electron source with a carbon concentrations of $7.5 \mathrm{~g} \mathrm{~L}^{-1}$ were compared (see Fig. 5). In Fig. 5, averages of the current densities in the stationary phase of the cells are shown. While glycerol performed practically the same in both configurations, acetate provided a considerable boost to current production in the divided reactor, more than doubling the $17 \mathrm{~mA} \mathrm{~m}^{-2}$ obtained with the undivided one. The increased power production of acetate in conventional cells is related to its higher selectivity toward exoelectrogenic pathways which leads to a reduced bacterial diversification [33].

When Mohan and co-workers operated their reactor in the presence or in the absence of a proton exchange membrane (PEM) [16], the membraneless MFC performed worse than the other. In that case both anode and cathode were compact graphite, while in our reactor the anode is a piece of carbon felt. This is not a secondary aspect: anaerobicity can be achieved in the core of the felt even into an opened reactor, while it is very unlikely that a graphite plate close to the

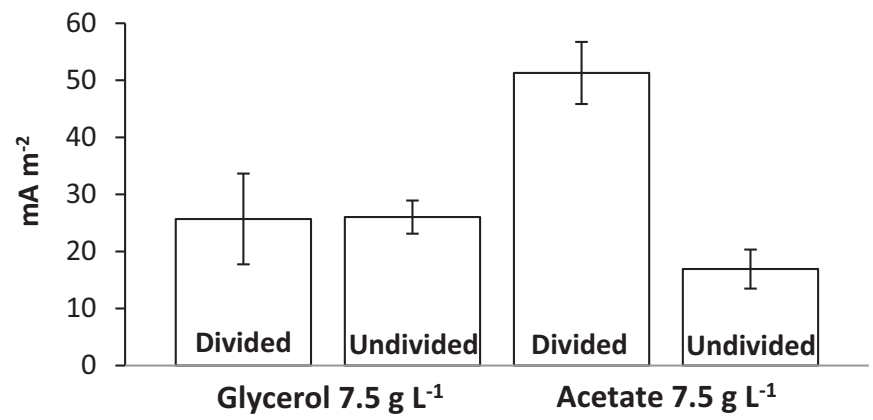

Fig. 5. One week averaged current density of SCML-MFCs (undivided) operated in semicontinuous mode with a hydraulic retention time of 3 days compared with conventional (divided) MFCs. Anode: carbon felt. Cathode: compact graphite. Membrane: Nafion. Divided reactors were operated with an opened anode chamber to replicate same conditions of the undivided ones. Glycerol and acetate based defined media at carbon concentration $7500 \mathrm{mg}_{\mathrm{c}} \mathrm{L}^{-1}$.

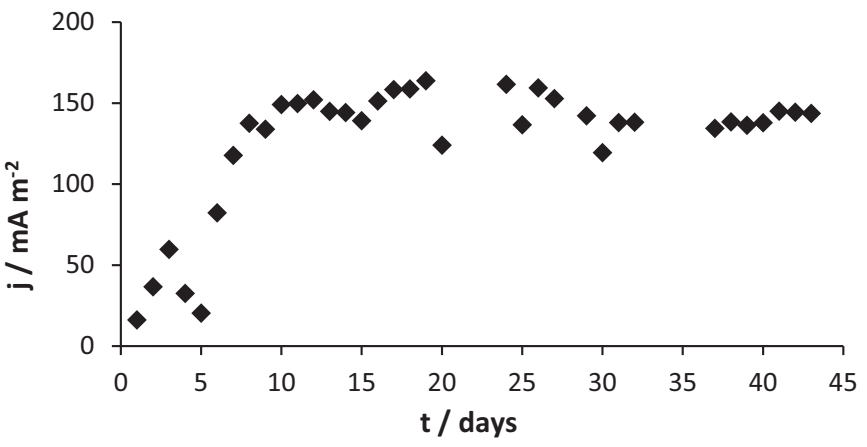

Fig. 6. Current densities in time for SCML-MFC operated in continuous mode with a hydraulic retention time of 3 days. Horizontal compact graphite cathode and vertical carbon felt anode $\left(\mathrm{S}=10.5 \mathrm{~cm}^{2}\right)$. Glycerol $3 \mathrm{~g}_{\mathrm{c}} \mathrm{L}^{-1}$ of defined media supplemented with $33 \mathrm{mM}$ of $\mathrm{NH}_{4} \mathrm{NO}_{3}$.

atmosphere can be surrounded by anaerobic bacteria.

\subsection{Comparison between vertical and horizontal cathode}

During batch mode tests, the effect of the horizontal cathode was evaluated using two identical reactors fed with glycerol at $7.5 \mathrm{~g}_{\mathrm{c}} \mathrm{L}^{-1}$. Steady state average current production with the vertical cathode rose from 0.04 to about $0.06 \mathrm{~mA}$ in the absence of nitrate, similarly to what found using Shewanella putrefaciens [18]. For this reason, some experiments were started with continuous mode and a horizontal cathode. Cell behavior using $3 \mathrm{~g}_{\mathrm{c}} \mathrm{L}^{-1}$ of glycerol and nitrates can be observed in Fig. 6.

After 45 days of operations the following conditions were analyzed:

i) No changes: horizontal cathode and presence of nitrates;

ii) Horizontal cathode and absence of nitrates;

iii) Vertical cathode and absence of nitrates;

iv) Vertical cathode and presence of nitrates.

For every aforementioned condition open circuit voltage (OCV), electrodes OCP and polarization measurements were performed. Cell acclimation before electrochemical measure in those condition was prolonged for at least 2 weeks. Results are summarized in Table 2 and Fig. 7.

With the horizontal cathode, when nitrates were used, cell OCV decreased. This outcome can be attributed to the reduced cathodic OCP that reflects the different final electron acceptor used, since reduction potential of oxygen in neutral $\mathrm{pH}$ environment is slightly higher than nitrates one $(+0.82 \mathrm{~V}$ against $+0.74 \mathrm{~V})$ [42]. Nevertheless, maximum power densities reached during both steady state and polarizations were more elevated when nitrates were present; at the same time internal resistance was minimized (see Table 2).

Last results contradict what found by Zhang and co-workers during

Table 2

Single chamber membraneless (SCML) MFC without air cathode. Peak power production, anodic and cathodic open circuit potentials (OCPs) varying cathode positioning and $\mathrm{NH}_{4} \mathrm{NO}_{3}$ (nitrates $33 \mathrm{mM}$ ) presence. Fed was defined media as described in Materials and methods section at $3 \mathrm{~g}_{\mathrm{c}} \mathrm{L}^{-1}$ of glycerol.

\begin{tabular}{|c|c|c|c|c|c|c|}
\hline \multirow[t]{2}{*}{ Cathode } & \multirow[t]{2}{*}{ Nitrates } & \multicolumn{2}{|c|}{$\begin{array}{l}\text { Peak power } \\
{\left[\mathrm{mW} \mathrm{m}^{-2}\right]}\end{array}$} & \multirow{2}{*}{$\begin{array}{l}\text { Anode } \\
\text { OCP } \\
{[\mathrm{mV} \text { vs }} \\
\text { SCE }]\end{array}$} & \multirow{2}{*}{$\begin{array}{l}\text { Cathode } \\
\text { OCP [mV } \\
\text { vs SCE] }\end{array}$} & \multirow[t]{2}{*}{$\mathbf{R}_{\text {int }}[\mathbf{\Omega}]$} \\
\hline & & $\begin{array}{l}\text { Steady } \\
\text { state }\end{array}$ & Polarization & & & \\
\hline Horizontal & Yes & 21.7 & 47.1 & -543 & -256 & 450 \\
\hline Horizontal & No & 7.2 & 27.6 & -520 & -155 & 1316 \\
\hline Vertical & No & 0.3 & 3.52 & -498 & -428 & 282 \\
\hline Vertical & Yes & 3.6 & 4.8 & -408 & -245 & 1423 \\
\hline
\end{tabular}




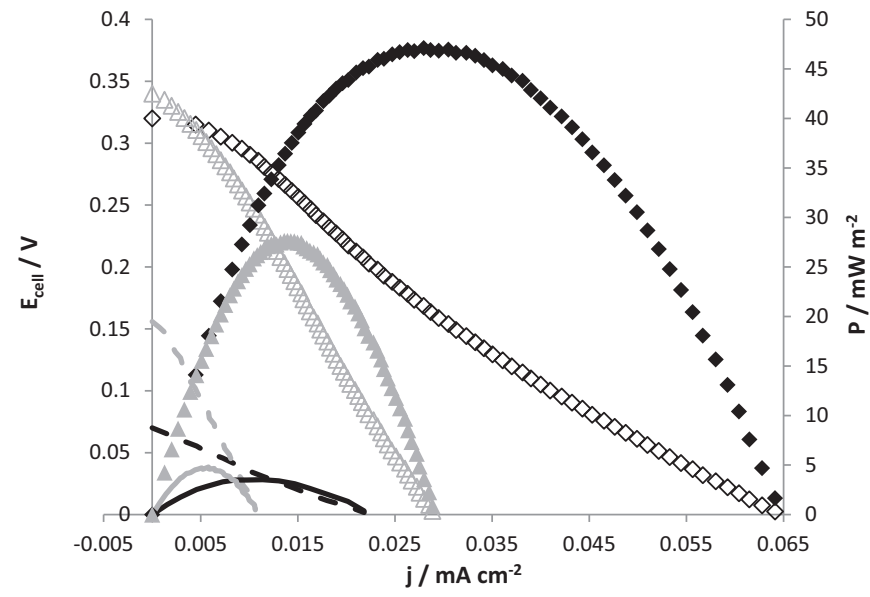

Fig. 7. Power density (right axis) and polarization curves (left axis) for single chamber membraneless (SCML) MFC without air cathode operated in continuous mode with a hydraulic retention time of 3 days. Black diamonds $(\diamond, \diamond)$ : horizontal cathode with $\mathrm{NH}_{4} \mathrm{NO}_{3}$. Grey triangles $(\triangle, \Delta)$ : horizontal cathode without $\mathrm{NH}_{4} \mathrm{NO}_{3}$. Black lines $(--,-$ - ): vertical cathode without $\mathrm{NH}_{4} \mathrm{NO}_{3}$. Grey lines (-, - -): vertical cathode with $\mathrm{NH}_{4} \mathrm{NO}_{3}$. The continuous lines and the empty symbols represent the polarization while the dashed lines and the full symbols the power density curves. Horizontal compact graphite cathode and vertical carbon felt anode $\left(S=10.5 \mathrm{~cm}^{2}\right)$. Glycerol $3 \mathrm{gc}_{\mathrm{c}} \mathrm{L}^{-1}$ of defined media. When present, nitrates concentration was $33 \mathrm{mM}$.

CVs of their SCML-MFC [26]. This can be explained by the stable biofilm on cathode surface that, in the present work, had more than one month of time to grow visibly, while no acclimation to nitrates was allowed in Zhang work [26]. Bacterial catalytic action on nitrates reduction is evidenced by the proximity of cathodic OCPs in presence of nitrates independently by cathode position $(-256 \mathrm{mV}$ for horizontal and $-245 \mathrm{mV}$ for vertical). A significant rise in power production was given by horizontal placement (Table 2).

As stated in the case of Shewanella putrefaciens [18], a hypothesis can be done based on oxygen distribution profile: in the bulk of the reactor anaerobic condition can be obtained by bacteria, affecting oxygen and nitrate reduction while, when cathode is half exposed to air it can exploit greatly both electron acceptor since oxygen at the interface between atmosphere and solution has a higher concentration and denitrifying bacteria are mostly facultative and can catalyze nitrate reduction also in the presence of other final electron acceptors [51].

A similar scenario can be seen in the ammonia concentration profile and nitrate absence found by Ieropoulos team using urine [24]. Finally, maximum power density recorded during polarization test was of $47.1 \mathrm{~mW} \mathrm{~m}^{-2}$, which is higher than that achieved in divided reactors operating in similar conditions such as the one proposed by Asensio et al. ( $40.0 \mathrm{~mW} \mathrm{~m}^{-2}, 5 \mathrm{~g}_{\mathrm{o} 2} \mathrm{~L}^{-1}$ (COD) of glycerol and 3 days of HRT) [40], stating again that SCML-MFCs can compete with conventional MFCs in terms of energy production with a largely cheaper configuration.

\section{Conclusions}

Already in 2006, Aelterman envisaged that the future of MFCs was to be a complementary technology to conventional anaerobic digestion for wastewater treatment, while mass power production and coulombic efficiency maximization were not considered as final target [52]. Three main outcomes where to be achieved in Aelterman opinion: (i) new cathodic materials for oxygen reduction reaction; (ii) cheaper configurations and (iii) a reliable energy output for non-commercial purpose (since energy market is not the target).

Examining results achieved more than 10 years later, it is possible to imagine that the integration depicted by Aelterman is very close: i) as shown by Santoro et Al. bio-cathodes represent a valid alternative to conventional expensive ORR catalyst [27]; ii) SCML-MFCs development constitutes a true breakthrough in cost minimization; iii) Ieropoulos group developed a reliable SCML-MFC system that can be integrated in any urinal and constitute a reliable "non-commodity" source of energy [25]. Time can thus be ready for scale-up. In this perspective, a niche has to be found for appropriate development of SCML. From the present work, four main concepts can be taken:

- Studies on the effect of substrates on the performance of MFCs conduced with conventional divided reactors cannot be extended to open-air undivided cells. Indeed, we have demonstrated that higher order substrates such as glycerol are more effective of simpler substrates like acetate in SCML current production, since they probably allow an increased bio-diversity which is essential for bio-cathodic community development.

- Changes recorded in cathode potential and maximum power in the presence of nitrates underline that the biocathodic community can take advantage of the presence of nitrates.

- It is possible to minimize costs avoiding the usage of both membrane and cathode catalyst thanks to a proper electrode orientation (i.e. horizontal, half submerged cathode).

- Reliability was increased changing feeding modality from batch to continuous mode at the HRT of 3 days.

All of these findings point to a possible niche, as those claimed by Aelterman, which is the next development of this research line: glycerol-rich wastewater treatment. Biodiesel production was reported to always produce glycerol as side product either from chemical or enzymatic strategies [53]. Anaerobic digestion is the elective process for this kind of residuals, but the lack of nitrogen may infer bacterial community development [54]. Thus, nitrate addition seems already to be needed, opening the possibility to test our device "as it is" with real industrial wastewater.

\section{Acknowledgments}

Prof. Michele Torregrossa and colleagues of wastewater treatment laboratory, 'Dipartimento di Ingegneria Civile, Ambientale, Aerospaziale, dei Materiali (DICAM)', University of Palermo, are thankfully acknowledged for providing the sludge used as inoculum.

\section{References}

[1] J.A. Trainham, V. Atiemo-Obeng, M.D. Bertolucci, J.F. Brennecke, B.W. Cue, J. De Graeve, J.E. Hutchison, A. Larson, P.G. Marrone, F. Wood-Black, K. Lai, T.M. Masciangioli, E. McGowan, S.A. Paige, D.C. Rasmussen, D. Zolandz, Sustainability in the Chemical Industry, National Academies Press, Washington, D.C., 2005, http://dx.doi.org/10.17226/11437.

[2] P. Würtz, A. Annila, Ecological succession as an energy dispersal process, Biosystems 100 (2010) 70-78, http://dx.doi.org/10.1016/j.biosystems.2010.01. 004.

[3] B.E. Logan, K. Rabaey, Conversion of wastes into bioelectricity and chemicals by using microbial electrochemical technologies, Science (80-.) (337) (2012) 686-690, http://dx.doi.org/10.1126/science.1217412.

[4] R. Kumar, L. Singh, Z.A. Wahid, M.F.M. Din, Exoelectrogens in microbial fuel cells toward bioelectricity generation: a review, Int. J. Energy Res. 39 (2015) 1048-1067, http://dx.doi.org/10.1002/er.3305.

[5] P. Pandey, V.N. Shinde, R.L. Deopurkar, S.P. Kale, S.A. Patil, D. Pant, Recent advances in the use of different substrates in microbial fuel cells toward wastewater treatment and simultaneous energy recovery, Appl. Energy 168 (2016) 706-723, http://dx.doi.org/10.1016/j.apenergy.2016.01.056.

[6] S.M. Daud, B.H. Kim, M. Ghasemi, W.R.W. Daud, Separators used in microbial electrochemical technologies: current status and future prospects, Bioresour. Technol. 195 (2015) 170-179, http://dx.doi.org/10.1016/j.biortech.2015.06.105.

[7] C. Feng, F. Li, H. Liu, X. Lang, S. Fan, A dual-chamber microbial fuel cell with conductive film-modified anode and cathode and its application for the neutral electro-Fenton process, Electrochim. Acta 55 (2010) 2048-2054, http://dx.doi.org/ 10.1016/j.electacta.2009.11.033.

[8] M.A.F. de A.F. de Dios, O. Iglesias, E. Bocos, M. Pazos, M.A.A. Sanromán, Application of benthonic microbial fuel cells and electro-Fenton process to dye decolourisation, J. Ind. Eng. Chem. 20 (2014) 3754-3760, http://dx.doi.org/10. 1016/j.jiec.2013.12.075.

[9] C.H. Feng, F.B. Li, H.J. Mai, X.Z. Li, Bio-electro-fenton process driven by microbial fuel cell for wastewater treatment, Environ. Sci. Technol. 44 (2010) 1875-1880, 
http://dx.doi.org/10.1021/es9032925.

[10] G. Riccobono, G. Pastorella, F. Vicari, A. D'Angelo, A. Galia, P. Quatrini, O. Scialdone, Abatement of AO7 in a divided microbial fuel cells by sequential cathodic and anodic treatment powered by different microorganisms, J. Electroanal. Chem. 799 (2017) 293-298, http://dx.doi.org/10.1016/j.jelechem. 2017.06.003.

[11] K. Ben Liew, W.R.W. Daud, M. Ghasemi, J.X. Leong, S. Su Lim, M. Ismail, Non-Pt catalyst as oxygen reduction reaction in microbial fuel cells: a review, Int. J. Hydrog. Energy 39 (2014) 4870-4883, http://dx.doi.org/10.1016/j.ijhydene.2014. 01.062.

[12] C.E. Reimers, L.M. Tender, S. Fertig, W. Wang, Harvesting energy from the marine sediment-water interface, Environ. Sci. Technol. 35 (2001) 192-195, http://dx. doi.org/10.1016/j.jpowsour.2008.06.079.

[13] N. Touch, T. Hibino, Y. Nagatsu, K. Tachiuchi, Characteristics of electricity generation and biodegradation in tidal river sludge-used microbial fuel cells, Bioresour. Technol. 158 (2014) 225-230, http://dx.doi.org/10.1016/j.biortech.2014.02.035.

[14] K. Scott, C. Murano, A study of a microbial fuel cell battery using manure sludge waste, J. Chem. Technol. Biotechnol. 82 (2007) 809-817, http://dx.doi.org/10. 1002/jctb.1745.

[15] R. Saravanan, A. Arun, S. Venkatamohan, Jegadeesan, T. Kandavelu, Veeramanikandan, Membraneless dairy wastewater-sediment interface for bioelectricity generation employing sediment microbial fuel cell (SMFC), Afr. J. Microbiol. Res. 4 (2010) 2640-2646.

[16] S.V. Mohan, K. Chandrasekhar, Solid phase microbial fuel cell (SMFC) for harnessing bioelectricity from composite food waste fermentation: influence of electrode assembly and buffering capacity, Bioresour. Technol. 102 (2011) 7077-7085, http://dx.doi.org/10.1016/j.biortech.2011.04.039.

[17] Z. Liu, X. Li, B. Jia, Y. Zheng, L. Fang, Q. Yang, D. Wang, G. Zeng, Production of electricity from surplus sludge using a single chamber floating-cathode microbial fuel cell, Water Sci. Technol. 60 (2009) 2399, http://dx.doi.org/10.2166/wst.2009. 313.

[18] F. Vicari, A. D'Angelo, A. Galia, P. Quatrini, O. Scialdone, A single-chamber membraneless microbial fuel cell exposed to air using Shewanella putrefaciens, J. Electroanal. Chem. 783 (2016) 268-273, http://dx.doi.org/10.1016/j.jelechem. 2016.11.010.

[19] A. Aldrovandi, E. Marsili, L. Stante, P. Paganin, S. Tabacchioni, A. Giordano, Sustainable power production in a membrane-less and mediator-less synthetic wastewater microbial fuel cell, Bioresour. Technol. 100 (2009) 3252-3260, http:// dx.doi.org/10.1016/j.biortech.2009.01.041.

[20] D. Jiang, B. Li, Granular activated carbon single-chamber microbial fuel cells (GACSCMFCs): a design suitable for large-scale wastewater treatment processes, Biochem. Eng. J. 47 (2009) 31-37, http://dx.doi.org/10.1016/j.bej.2009.06.013.

[21] F. Zhu, W. Wang, X. Zhang, G. Tao, Electricity generation in a membrane-less microbial fuel cell with down-flow feeding onto the cathode, Bioresour. Technol. 102 (2011) 7324-7328, http://dx.doi.org/10.1016/j.biortech.2011.04.062.

[22] H. Hiegemann, D. Herzer, E. Nettmann, M. Lübken, P. Schulte, K.-G. Schmelz, S. Gredigk-Hoffmann, M. Wichern, An integrated 45L pilot microbial fuel cell system at a full-scale wastewater treatment plant, Bioresour. Technol. 218 (2016) 115-122, http://dx.doi.org/10.1016/j.biortech.2016.06.052.

[23] V.R. Nimje, C.C. Chen, H.R. Chen, C.Y. Chen, M.J. Tseng, K.C. Cheng, R.C. Shih, Y.F. Chang, A single-chamber microbial fuel cell without an air cathode, Int. J. Mol. Sci. 13 (2012) 3933-3948, http://dx.doi.org/10.3390/ijms13033933.

[24] X.A. Walter, I. Gajda, S. Forbes, J. Winfield, J. Greenman, I. Ieropoulos, Scaling-up of a novel, simplified MFC stack based on a self-stratifying urine column, Biotechnol. Biofuels 9 (2016) 93, , http://dx.doi.org/10.1186/s13068-016-0504-3.

[25] X. Alexis, A. Stinchcombe, J. Greenman, I. Ieropoulos, Urine transduction to usable energy: a modular MFC approach for smartphone and remote system charging, Appl. Energy 192 (2017) 575-581, http://dx.doi.org/10.1016/j.apenergy.2016.06. 006.

[26] G. Zhang, H. Zhang, C. Zhang, G. Zhang, F. Yang, G. Yuan, F. Gao, Simultaneous nitrogen and carbon removal in a single chamber microbial fuel cell with a rotating biocathode, Process Biochem. 48 (2013) 893-900, http://dx.doi.org/10.1016/j. procbio.2013.03.008.

[27] C. Santoro, Y. Lei, B. Li, P. Cristiani, Power generation from wastewater using single chamber microbial fuel cells (MFCs) with platinum-free cathodes and pre-colonized anodes, Biochem. Eng. J. 62 (2012) 8-16, http://dx.doi.org/10.1016/j.bej.2011.12. 006.

[28] H. Liu, H. Liu, R. Ramnarayanan, R. Ramnarayanan, B.E. Logan, B.E. Logan, Production of electricity during wastewater treatment using a single chamber microbial fuel cell, Environ. Sci. Technol. 38 (2004) 2281-2285, http://dx.doi.org/10. 1021/es034923g.

[29] B.E. Logan, M.J. Wallack, K. Kim, W. He, Y. Feng, P.E. Saikaly, Assessment of microbial fuel cell configurations and power densities, Environ. Sci. Technol. Lett. 2 (2015) 206-214, http://dx.doi.org/10.1021/acs.estlett.5b00180.

[30] L.E.B. Liu Hong, Electricity generation using an air-cathode single chamber microbial fuel cell in the presence and absence of a proton exchange membrane, Environ. Sci. Technol. 38 (2004) 4040-4046, http://dx.doi.org/10.1021/ es0499344.

[31] T. Tommasi, G. Lombardelli, Energy sustainability of Microbial Fuel Cell (MFC): a case study, J. Power Sources 356 (2017) 438-447, http://dx.doi.org/10.1016/ jpowsour.2017.03.122.

[32] Z. Liu, J. Liu, S. Zhang, Z. Su, Study of operational performance and electrical response on mediator-less microbial fuel cells fed with carbon- and protein-rich substrates, Biochem. Eng. J. 45 (2009) 185-191, http://dx.doi.org/10.1016/j.bej. 2009.03.011.

[33] D. Pant, G. Van Bogaert, L. Diels, K. Vanbroekhoven, A review of the substrates used in microbial fuel cells (MFCs) for sustainable energy production, Bioresour. Technol. 101 (2010) 1533-1543, http://dx.doi.org/10.1016/j.biortech.2009.10. 017.

[34] G. Mannina, M. Capodici, A. Cosenza, D. Di Trapani, Carbon and nutrient biological removal in a University of Cape Town membrane bioreactor: analysis of a pilot plant operated under two different C/N ratios, Chem. Eng. J. 296 (2016) 289-299, http://dx.doi.org/10.1016/j.cej.2016.03.114.

[35] B. Min, B.E. Logan, Continuous electricity generation from domestic wastewater and organic substrates in a flat plate microbial fuel cell, Environ. Sci. Technol. 38 (2004) 5809-5814, http://dx.doi.org/10.1021/Es0491026.

[36] K. Rabaey, P. Clauwaert, P. Aelterman, W. Verstraete, Tubular microbial fuel cells for efficient electricity generation, Environ. Sci. Technol. 39 (2005) 8077-8082, http://dx.doi.org/10.1021/es050986i.

[37] H.-S. Lee, P. Parameswaran, A. Kato-Marcus, C.I. Torres, B.E. Rittmann, Evaluation of energy-conversion efficiencies in microbial fuel cells (MFCs) utilizing fermentable and non-fermentable substrates, Water Res. 42 (2008) 1501-1510, http://dx. doi.org/10.1016/j.watres.2007.10.036.

[38] S. Wang, L. Huang, L. Gan, X. Quan, N. Li, G. Chen, L. Lu, D. Xing, F. Yang, Combined effects of enrichment procedure and non-fermentable or fermentable cosubstrate on performance and bacterial community for pentachlorophenol degradation in microbial fuel cells, Bioresour. Technol. 120 (2012) 120-126, http:// dx.doi.org/10.1016/j.biortech.2012.06.022.

[39] C.-Y. Chen, T.-Y. Chen, Y.-C. Chung, A comparison of bioelectricity in microbial fue cells with aerobic and anaerobic anodes, Environ. Technol. 35 (2014) 286-293, http://dx.doi.org/10.1080/09593330.2013.826254.

[40] Y. Asensio, C.M. Fernandez-Marchante, J. Lobato, P. Cañizares, M.A. Rodrigo, Influence of the fuel and dosage on the performance of double-compartment microbial fuel cells, Water Res. 99 (2016) 16-23, http://dx.doi.org/10.1016/j.watres. 2016.04.028.

[41] A. Sydow, T. Krieg, F. Mayer, J. Schrader, D. Holtmann, Electroactive bacteria-molecular mechanisms and genetic tools, Appl. Microbiol. Biotechnol. 98 (2014) 8481-8495, http://dx.doi.org/10.1007/s00253-014-6005-z.

[42] M. Madigan, J. Martinko, D. Stahl, D. Clark, Brock Biology of Microorganisms, 14th ed., Pearson, London, 2015.

[43] H. Biebl, K. Menzel, A.P. Zeng, W.D. Deckwer, Microbial production of 1,3-propanediol, Appl. Microbiol. Biotechnol. 52 (1999) 289-297, http://dx.doi.org/10. 1007/s002530051523.

[44] K.C. Wrighton, B. Virdis, P. Clauwaert, S.T. Read, R.A. Daly, N. Boon, Y. Piceno, G.L. Andersen, J.D. Coates, K. Rabaey, Bacterial community structure correspond to performance during cathodic nitrate reduction, ISME J. 4 (2010) 1443-1455, http://dx.doi.org/10.1038/ismej.2010.66.

[45] G. Zhu, T. Onodera, M. Tandukar, S.G. Pavlostathis, Simultaneous carbon removal, denitrification and power generation in a membrane-less microbial fuel cell, Bioresour. Technol. 146 (2013) 1-6, http://dx.doi.org/10.1016/j.biortech.2013.07. 032.

[46] G.-W. Chen, S.-J. Choi, T.-H. Lee, G.-Y. Lee, J.-H. Cha, C.-W. Kim, Application of biocathode in microbial fuel cells: cell performance and microbial community, Appl. Microbiol. Biotechnol. 79 (2008) 379-388, http://dx.doi.org/10.1007/ s00253-008-1451-0.

[47] K.P. Gregoire, S.M. Glaven, J. Hervey, B. Lin, L.M. Tender, Enrichment of a highcurrent density denitrifying microbial biocathode, J. Electrochem. Soc. 161 (2014) H3049-H3057, http://dx.doi.org/10.1149/2.0101413jes.

[48] S. Veer Raghavulu, S. Venkata Mohan, M. Venkateswar Reddy, G. Mohanakrishna, P.N. Sarma, Behavior of single chambered mediatorless microbial fuel cell (MFC) at acidophilic, neutral and alkaline microenvironments during chemical wastewater treatment, Int. J. Hydrog. Energy 34 (2009) 7547-7554, http://dx.doi.org/10. 1016/j.ijhydene.2009.05.071.

[49] Y. Zuo, S. Cheng, D. Call, B.E. Logan, Tubular membrane cathodes for scalable power generation in microbial fuel cells, Environ. Sci. Technol. 41 (2007) 3347-3353, http://dx.doi.org/10.1021/es0627601.

[50] M.B. Viana, A.V. Freitas, R.C. Leitão, G.A.S. Pinto, S.T. Santaella, Anaerobic digestion of crude glycerol: a review, Environ. Technol. Rev. 1 (2012) 81-92, http:// dx.doi.org/10.1080/09593330.2012.692723.

[51] H. Lu, K. Chandran, D. Stensel, Microbial ecology of denitrification in biological wastewater treatment, Water Res. 64 (2014) 237-254, http://dx.doi.org/10.1016/ j.watres.2014.06.042.

[52] T.H. Pham, K. Rabaey, P. Aelterman, P. Clauwaert, L. De Schamphelaire, N. Boon W. Verstraete, Microbial fuel cells in relation to conventional anaerobic digestion technology, Eng. Life Sci. 6 (2006) 285-292, http://dx.doi.org/10.1002/elsc. 200620121.

[53] J. Ángel, S. López, M.D.L. Ángeles, M. Santos, A. Francisco, C. Pérez, A.M. Martín, Bioresource technology anaerobic digestion of glycerol derived from biodiesel manufacturing, Bioresour. Technol. 100 (2009) 5609-5615, http://dx.doi.org/10. 1016/j.biortech.2009.06.017.

[54] C. Santibáñez, M.T. Varnero, M. Bustamante, Residual glycerol from biodiesel manufacturing, waste or potential source of bioenergy: a review, Chil. J. Agric. Res. 71 (2011) 469-475 https://www.scopus.com/inward/record.uri?eid=2-s2.084856426719\&partnerID $=40 \&$ md5 = 2a24891611b6cc9dd0d458e0c149b47b. 